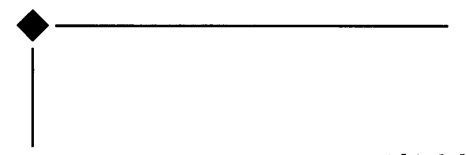

\title{
当科における最近 5 年間の腹腔鏡手術の現況 Study of laparoscopic surgery in our hospital during recent 5 years
}

済生会宇都宮病院産婦人科

中田浩一、未盛友浩、湯山公美子、須藤慎介、細川知俊、飯田俊彦

\section{緒言}

近年、腹腔鏡関連器機はさまざまに工夫され、 その進歩には目を見張るものがある。さらに患者 サイドからの腹腔鏡手術に対する要請の増加とも あいまって、腹腔鏡手術は婦人科良性疾患の手術 には必須のものとなっている。当科では、新病院 に移転した1996年より腹腔鏡関連器機を整備し腹 腔鏡手術を本格的に導入した。症例数は徐々に増 え、2003年は婦人科良性疾患の手術全体の約 $29 \%$ を占めるまでになった。そこで、症例数が急速に 増えてきた最近 5 年間の当科における腹腔鏡手術 の歩みを総括し、今後の課題、目標等を検討した。 なお、本論文中の “婦人科良性疾患手術”とは、 帝王切開、人工妊娠中絶、流産手術、頸管縫縮術 などの産科手術および子宮頸部円錐切除術を含め た悪性腫瘍に関する婦人科手術を除いた手術と定 義する。

\section{対象および方法}

1999年 1 月 1 日より 2003 年 12 月末日までの 5 年 間に、当科において施行した腹腔鏡手術 374 例を 対象とした。とくに腹腔鏡手術の適応決定は厳密 に行うように留意した。卵巣囊腫では、エコーだ けでなく必ずCTあるいはMRIにより悪性所見の 有無を検討し、多少でもその疑いのあるものは開 腹手術を選択した。また、以前に開腹手術の既往 のある場合、子宮内膜症、骨盤腹膜炎などの炎症 性疾患の既往のある場合、BMI26以上の場合など では開腹手術への変更もある旨を十分にインフォ ームドコンセントした上で手術を行った。麻酔は、 全例全身麻酔を使用し、2001年 9 月までは全例 $\mathrm{CO}_{2}$ 気腹法、それ以後は、主に瑞穂医科工業製腹壁全
層吊り上げ鈎を用いた吊り上げ式（以下、吊り上 げ式）で行った。手術前日入院、第 1 病日夕より 流動食開始、第 2 病日まで抗生剤を点滴投与、第 4 病日の退院とした。

\section{結果}

1、腹腔鏡手術件数の年次推移（図 1 )

図 1 に各手術の年次推移を示す。手術件数は、 1999年より年間10～20件前後の割合で増加してい る。最近 5 年間での腹腔鏡手術の全婦人科良性疾 患手術に対する割合は総数1688件に対し358件で、 約 $21.2 \%$ 腹腔鏡により行われており、昨年は 368件に対し107件で約 $29.1 \%$ 占めた。

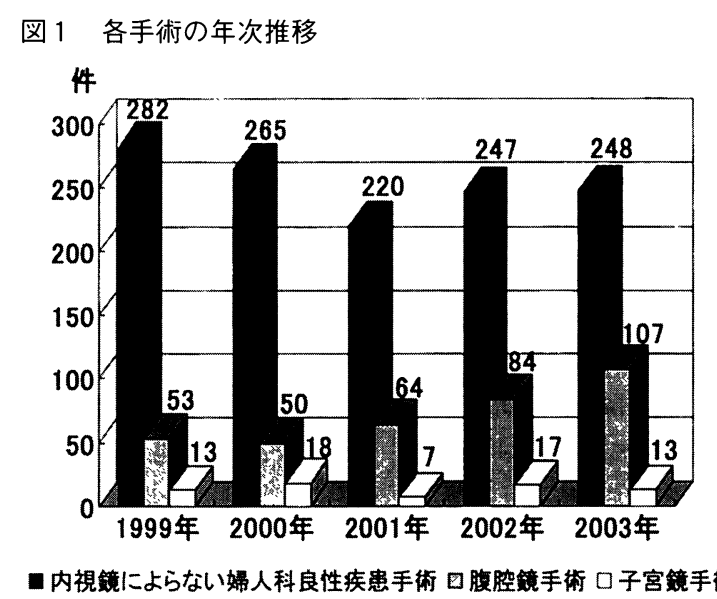

2、腹腔鏡手術施行対象疾患（図 2)

図 2 に腹腔鏡手術を施行した疾患の割合を示 す。卵巣囊腫、子宮外妊娠、子宮筋腫、子宮内膜 症の 4 疾患で全体の $87 \%$ を占めている。不妊症症 例の中で子宮内膜症、腹腔内癒着、子宮筋腫など を合併した症例については、それぞれの疾患に含 め不妊症症例とはしなかった。不妊症症例は、手 
術的操作を加えず腹腔内観察や色素通水試験のみ で終わった症例のみである。

\section{図 2 腹腔鏡手術の適応症}

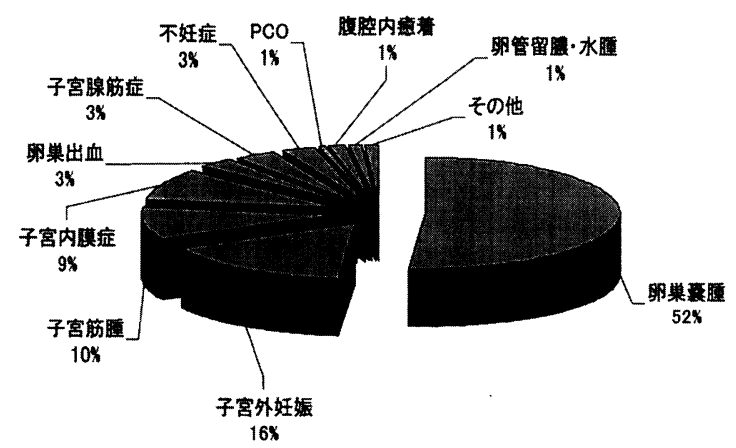

3、腹腔鏡手術の術式（図 3、図 4）

図 3 は各腹腔鏡手術の割合を示したものであ る。卵巣囊腫摘出が最も多く $38 \%$ を占める。以下、 付属器切除、子宮外妊娠手術、観察 - 瘉着剥離、 筋腫核出の順となっている。2002、2003年と襄腫 摘出が著しく増加した。図 4 は上位 4 つの術式に ついて最近 5 年間の開腹手術と腹腔鏡手術の割合 を見たものである。各術式とも左より1999、2000、 2001、2002、2003年の順になっている。2003年は 卵巣囊腫摘出の $73 \%$ 、子宮外妊娠手術では $82 \%$ が 腹腔鏡手術であった。一方、付属器切除は $38 \%$ 、 筋腫核出は $18 \%$ で腹腔鏡手術の実施率が低い。ま

\section{図 3 腹腔鏡手術の術式}

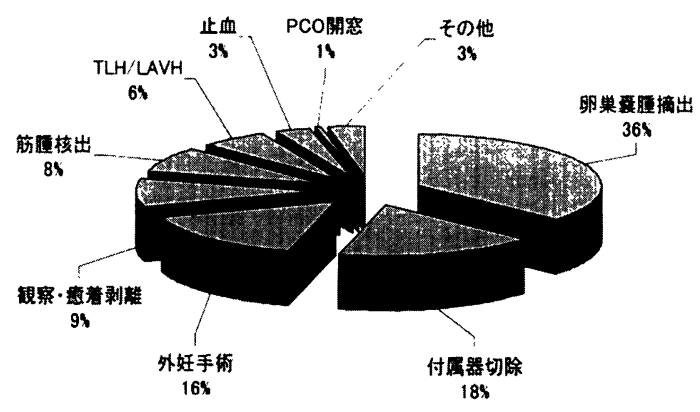

図 4 主な腹腔鏡手術の年次推移

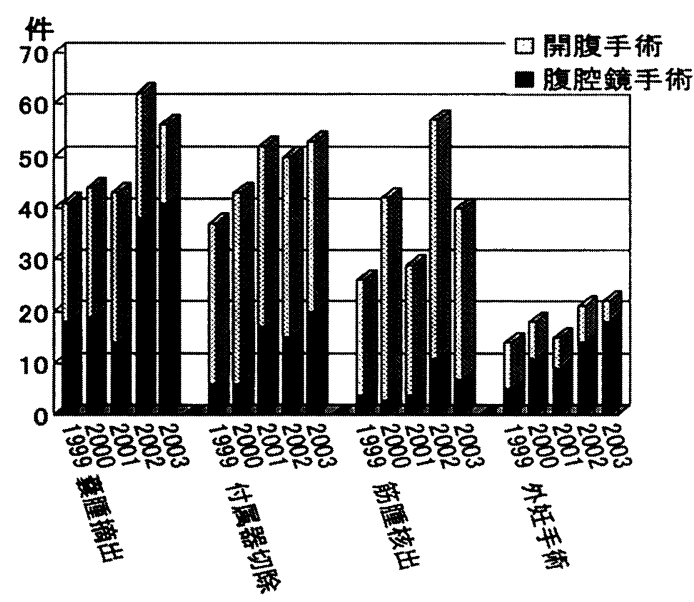

た、1999年から2001年までの 3 年間と2002年から 2003年までの 2 年間に注目すると、いずれの術式 とも最近 2 年間の方が腹腔鏡手術の割合が高く、 年々、腹腔鏡手術の割合が増えてきている。

\section{4、開腹手術に変更された症例（表 $1 、 2 ）$}

表 1 は腹腔鏡手術を予定していたものの何らか の理由により開腹手術に変更された症例を示して いる。開腹手術への移行率は、腹腔鏡予定手術 374 例中 16 例で $4.3 \%$ あっった。子宮内膜症、過去 の開腹手術、骨盤内炎症などによる腹腔内癒着が 主な理由になっている。その他、肥満により術前 の予想以上に術野の確保が困難だったもの、腹腔 内出血により術野の確保が困難になったものなど もあった。表 2 は主な術式の開腹手術への移行率 を示したものである。TLHやLAVHの開腹移行 例がとくに高率になっている。

表 1 開腹手術となった症例

\begin{tabular}{|c|c|c|c|c|}
\hline & 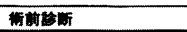 & 予定䀺式 & 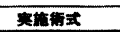 & 辕由 \\
\hline 1 & 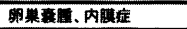 & 曋愿摛出 & 同在 & 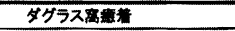 \\
\hline 2 & 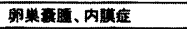 & 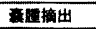 & 同在 & 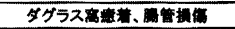 \\
\hline 3 & 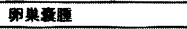 & 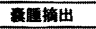 & 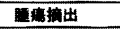 & 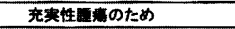 \\
\hline 4 & 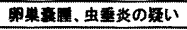 & 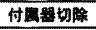 & 同左+蛙玮切除 & 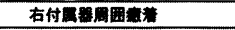 \\
\hline 5 & 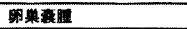 & 付風箁切除 & 周左 & 既往帝切による急潇 \\
\hline 6 & 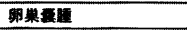 & 付風器切賖 & 周左 & 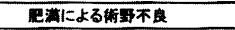 \\
\hline 7 & 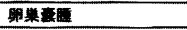 & 付風畾切除 & 同左 & 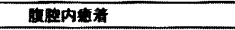 \\
\hline 8 & 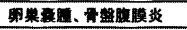 & 付風器切除 & 同左 & 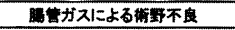 \\
\hline 9 & 子宫外娃缍 & 鼠管切除 & 同左 & 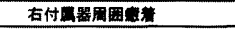 \\
\hline 10 & 7宾外弤幆 & 舄管切除 & 同在 & 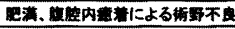 \\
\hline 11 & 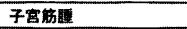 & 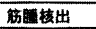 & 同在 & 出血による待野不良 \\
\hline 12 & 7 蔓箷㢆 & 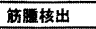 & 周左 & 子富可勘性不良 \\
\hline 13 & 子它解睡 & LAVH & ATH & 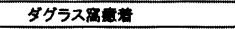 \\
\hline 14 & 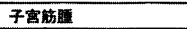 & $\mathrm{TLH}$ & ATH & 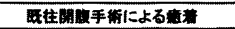 \\
\hline 15 & 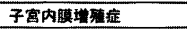 & $\mathrm{TLH}$ & ATH & 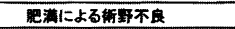 \\
\hline 16 & 子宮脱 & LAVH & ATH & 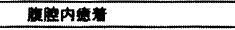 \\
\hline
\end{tabular}

表 2 主な術式の開腹手術移行率

\begin{tabular}{|c|c|c|c|}
\hline & 総手術数 & 開腹移行数 & 開獥移行事 \\
\hline 卵果毫缰摘出 & 134 & 3 & $2.24 \%$ \\
\hline 付属器切除 & 69 & 5 & $7.25 \%$ \\
\hline 外妊手術 & 59 & 2 & $3.39 \%$ \\
\hline 筋腫核出 & 31 & 2 & $6.45 \%$ \\
\hline TLH/LAVH & 26 & 4 & $15.38 \%$ \\
\hline 総腹腔鏡手術 & 374 & 16 & $4.28 \%$ \\
\hline
\end{tabular}

5、合併症症例（表 3)

表 3 に合併症が発生した症例を示す。全腹腔鏡 手術に対する発生頻度は358例中 4 例で1.1\%であ った。内膜症による癒着剥離の際に直腸を損傷し たもの 1 例 $(0.3 \%) 、$ 膀胱を損傷したもの 2 例 $(0.6 \%) 、 ト ラ カ ー ル$ 挿入部の腹壁血管を損傷し 止血に窮したもの 1 例 $(0.3 \%)$ などである。さ らに、摘出した卵巣囊腫に明細胞腺癌を認め、後 日あらためて開腹し根治術および抗癌剤治療を行 った症例が 1 例 $(0.3 \%)$ あった。 
表 3 合併症症例

\begin{tabular}{|c|c|c|c|}
\hline & 街前造沙 & 俩式 & 合併应 \\
\hline 1 & 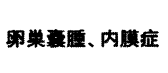 & 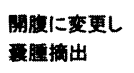 & 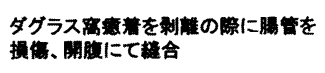 \\
\hline 2 & 腹啋精查目的 & 害洋剥誰 & 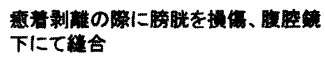 \\
\hline 3 & 卵伹要腫 & 要雷摘出 & 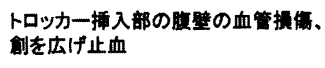 \\
\hline 4 & 子宫滕筋症 & TLH & 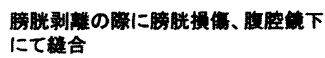 \\
\hline
\end{tabular}

\section{考察}

最近の腹腔鏡関連器機の進歩は目覚しく、また 腹腔鏡手術用器械もさまざまに工夫されている。 このため初心者でも比較的容易に腹腔鏡手術を手 がけやすい環境になっている。しかしその反面、 最近たびたびマスメディアで報道されているよう に技術の未熟さから重大な合併症をもたらす事例 が増えている。当院は栃木県抒よび宇都宮市の基 幹病院であり、患者サイドからの要請には可能な 限り応じ内視鏡手術を積極的に実施していく必要 があると、われわれは考えている。一方、教育研 修病院でもあるため医師の交代が頻繁で、当院に 赴任して初めて腹腔鏡を手にする医師も少なくな い。このような初心者への技術指導は、各医師の 資質もあり実際のところ非常に難しい。当科は、 はっきりと明文化された “腹腔鏡手術研修プログ ラム”なるものは持ち合わせていない。本人の資 質や希望に合わせ、ケースバイケースで判断し指 導しているのが実情である。以下に、当科で腹腔 鏡手術を実施、指導する際に留意している事項に つき $2 、 3$ 述べてみたい。

現在、腹腔鏡手術は 3 名の指導医のうち 1 名が 必ず術者を担当し、他に 1 名の研修医とともに 2 名で行っている。すでに述べたように最近 5 年間 では毎年50〜104件の腹腔鏡手術が行われている ので、指導医は毎年15 35件程度、最近 5 年間で は100〜120例程度の症例を担当していることにな る。指導医以外の医師（研修医を含む）も 3 名掠 り、同様に年間 $15 \sim 35$ 例程度の腹腔鏡手術に立ち 会うことができる。

最初に初心者が戸惑うのは腹腔内へのトロッカ 一挿入手技である。クローズド法による気腹針や トロッカーの挿入は恐怖感があり、また腸管損傷 や血管損傷をもっとも発生しやすいプロセスでも ある。当科では2001年 9 月以後はほとんど全例を 吊り上げ式にて行っている。吊り上げ式では吊り
上げ鈎の挿入はオープン法により行われ、腹腔内 の状況を確認できるので安全であり、初心者でも 比較的スムーズに修得できる。腹腔内の術野のひ ろがり感は気腹法にやや劣るものの、ほとんどの 腹腔鏡手術は吊り上げ式にて実施可能である。ま た、トロッカーを使用しないので経済的でもある。 トロッカー挿入時の合併症は、Bonjer $\mathrm{HJ}^{\mathrm{N}}{ }^{1)}$ の 報告によればオープン法では12444例中、腸管損 傷 $0.05 \%$ 、血管損傷 $0 \%$ 、クローズド法では 489335例中、腸管損傷、血管損傷ともに $0.08 \%$ 、 腸管損傷については有意差ないが、血管損傷の発 生率はオープン法で有意に低いとしている。

実際の手術手技については、10～20例程度助手 を経験した後、瘉着のない卯巣囊腫の症例で、囊 腫壁の切開、囊腫剥離、囊腫内容の穿刺吸引など の操作により、遠近感のそしい平面的なモニター 画面での手術操作に慣れるようにしている。われ われは、腹腔鏡手術の習得は、開腹手術の習得な くしては不可能なものと考えている。開腹手術で の手技がそのまま腹腔鏡手術で実行されるのが安 全で合理的な腹腔鏡手術の条件となる。したがっ て、開腹手術の手技も不十分な卒後 $1 \sim 2$ 年の研 修医には腹腔鏡手術は必要ないと考えている。開 腹手術を十分にマスターした上で、余裕があれば 腹腔鏡手術を始めるべきであろう。

指導する立場にあるわれわれも、腹腔鏡手術で は症例ごとに試行錯誤の連続である。術前に内診 所見、画像診断などにより腹腔鏡手術の適応を厳 密に診断したとしても、予期しない腹腔内癒着な どによる開腹手術への移行症例はある程度は避け られないものである。 5 年間の当科における開腹 手術移行症例は 374 例中 16 例、 $4.3 \%$ で、年による 偏りはなく毎年必ず数例はある。各文献で報告さ れている開腹移行率は0.311〜 4.745\%である ${ }^{2.7) 。 ~}$ 当科と同規模の症例数による報告では、開腹移行 率は当科とほぼ同程度か、当科がやや高い傾向が みられた。当科ではTLHやLAVHの開腹移行率 が高率になっているが、これはTLHやLAVHは 5 年間で 26 例と症例が少なく術式そのものに慣れ ていないことが最大の理由と考えられる。また、 各文献で報告されている腹腔鏡手術における合併 症とその頻度は、腸管損傷が $0.075 \sim 0.474 \%$ 、泌 尿器系損傷が $0.027 \sim 1.770 \%$ 、血管損傷が 0.037 $2.212 \%$ であり ${ }^{2-7)}$ 、当科では、腸管損傷、泌尿器

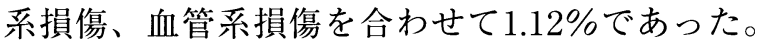
腹腔鏡手術の内容や術者の習熟度などの問題もあ り単純な比較はできないが、当科での合併症発生 
率は諸家の報告と大差ないようである。 Magrina $\mathrm{JF}^{8)}$ は、腸管損傷は術中に診断されにくく、そ の術中診断率は31〜 62\% と低く、発見が遅れ重篤 な結果をもたらすことが多いと述べている。当科 での合併症症例 4 例は、いずれも術中に判明し開 腹または腹腔鏡下で修復し事なきを得た。当然の ことではあるが、臟器損傷の回避で重要なのは手 術続行に困難を感じたときや何らかのトラブルが 発生したときには、患者の利益を第一に考元腹腔 鏡手術に拘泥せず撤退する勇気であると考える。

良性卵巣囊腫は腹腔鏡手術の良い適応であり、 術前に十分な検査を行い、覀性腫瘍を除外した上 で積極的に腹腔鏡手術を行うべきだと考えてい る。2002年以後当科での卵巣囊腫摘出術における 腹腔鏡手術の実施率は急増している。その理由と して、2002年は吊り上げ式の導入時期に一致して おり、吊り上げ式では切開創を大きくして体腔外 法を施行しやすくなり、比較的大きい卵巣囊腫で も術前精查で良性と診断されたものには積極的に 腹腔鏡手術を施行するようになったことが挙げら れる。一方、付属器切除術における腹腔鏡手術の 実施率は2003年が38\%でそれほど高くなく、また 増加傾向も認めていない。充実性部分を認める腫 瘍や大きな腫瘍は開腹による付属器切除を選択す ることが多く、したがって付属器切除では開腹手 術の割合が高くなるものと考えられた。また筋腫 核出術は、未婚患者や挙児希望患者に施行するこ とが多い。したがって、粘膜下や筋層内筋腫につ いては子宮内膜や卵管を損傷しないように、また 次回妊娠に備え子宮筋層の縫合をより確実にした いために、腹腔鏡手術の適応をかなり厳しく判断 しており、どうしても開腹手術が多くなる傾向が あった。

当科では、この 5 年間に 1 例だけ術後病理検査 にて明細胞腺癌を認めた内膜症性卵巣囊腫を経験 した。この症例は後日、開腹にて根治術を行った わけであるが、十分な術前検査をしてもなおこの ような症例は避けられないことを再認識した次第 である。Stern $\mathrm{RC}^{9)}$ らは手術的に診断された子 宮内膜症1000例に関して検索したところ、子宮内 膜症を有する卵巣の $5 \%$ 癌を認め、組織型では 明細胞腺癌、類内膜腺癌を高頻度に認めたと報告 している。また、Brinton LA ${ }^{10)}$ らは経過の長い 子宮内膜症患者では卵巣癌発生の相対頻度は 4.2 と高值であったと報告している。したがって、青 木ら ${ }^{11)}$ は内膜症性卵巣囊腫で経過観察中に充実 性部分が現れてきた場合、急速に増大した場合な
どでは術前にカラードップラー法、CT、MRIな どにより悪性所見の有無につき充分な検索を行う 必要があると述べている。

腹腔鏡関連器機の進歩により、今後ますます腹 腔鏡手術の実施者の裾野は広がっていくであろ う。このため、指導者の研鑽、初心者の教育は一 層重要になってくる。当科でも、これまでの経験 を踏まえ、なお一層患者サイドからの要請に応え られるように、これからも安全で確実な腹腔鏡手 術を心がけていきたい。

な㧍、本論文は第57回日本産科婦人科学会栃木地 方部会に拈いて発表した内容にさらにデータを追 加し加筆したものである。

\section{参考文献}

1 ) Bonjer HJ, et al: Open versus closed establishment of pneumoperitoneum in laparoscopic surgery. Br J Surg 84: 599, 1997

2 ) Jansen FW, et al.: Complications of laparoscopy : A prospective multicenter observational study. Br J Obstet Gynecol 104: 595, 1997

3 ) Chapron C, et al. : Surgical complications of diagnostic and operative gynaecological laparoscopy : A series of 29,966 cases. Hum Reprod 13: 867 . 1998

4) Harkki-Sieren P, Sjoberg J, Kurki T.: Major complications of laparoscopy: A follow-up finish study. Obstet Gynecol 94: 948, 1999

5 ) Saidi MH, et al: Complications of major operative laparoscopy. A review of 452 cases. J Reprod Med 41: 471, 1996

6) Mac Cordick C, et al.: Morbidity in laparoscopic gynecologic surgery: Results of a prospective single-center study. Surg Endosc 13: 571,1999

7 ) Mirhashemi R, et al: Predicting risk of complications with gynecologic laparoscopic surgery. Obstet Gynecol 92: 327, 1998

8) Magrina JF.: Complications of laparoscopic surgery. Clin Obstet Gynecol 45:469, 2002

9 ) Stern RC, et al.: Malignancy in endometriosis: frequency and comparison of ovarian and extraovarian types. Int J Gynecol Pathol 20: 133, 2001

10) Brinton LA, et al.: Cancer risk after a hospital discharge diagnosis of endometriosis. Am J Obstet Gynecol 176: 572, 1997

11）青木陽一、田中憲一：子宮内膜症治療のストラテ ジー；卵巣癌の合併、臨産婦、55：1355、2000 